\title{
Applying design of experiments (DOE) to flavonoid extraction from Passiflora alata and $P$. edulis
}

\section{Peky Noriega, ${ }^{1}$ Débora de Freitas Mafud, ${ }^{1}$ Bruna de Souza, ${ }^{1}$ Marta Soares-Scott, ${ }^{2}$ Diogo Pineda Rivelli, ${ }^{3}$ Silvia Berlanga de Moraes Barros, ${ }^{3}$ Elfriede Marianne Bacchi ${ }^{*}, 1$}

\author{
${ }^{1}$ Departamento de Farmácia, Faculdade de Ciências Farmacêuticas, \\ Universidade de São Paulo, Brazil, \\ ${ }^{2}$ Instituto Agronômico de Campinas, Brazil, \\ ${ }^{3}$ Departamento de Análises Clínicas e Toxicológicas, Faculdade de Ciências \\ Farmacêuticas, Universidade de São Paulo, Brazil.
}

\begin{abstract}
The Passifloraceae family is extensively used in native Brazilian folk medicine to treat a wide variety of diseases. The problem of flavonoid extraction from Passiflora was treated by application of design of experiments (DOE), as an experiment with mixture including one categorical process variable. The components of the binary mixture were: ethanol (component A) and water (component B); the categorical process variable: extraction method (factor $\mathrm{C}$ ) was varied at two levels: $(+1)$ maceration and (-1) percolation. ANOVA suggested a cubic model for $P$. edulis extraction and a quadratic model for $P$. alata. These results indicate that the proportion of components $\mathrm{A}$ and $\mathrm{B}$ in the mixture is the main factor involved in significantly increasing flavonoid extraction. In regard to the extraction methods, no important differences were observed, which indicates that these two traditional extraction methods could be effectively used to extract flavonoids from both medicinal plants. The evaluation of antioxidant activity of the extract by ORAC method showed that $P$. edulis displays twice as much antioxidant activity as $P$. alata. Considering that maceration is a simple, rapid and environmentally friendly extraction method, in this study, the optimized conditions for flavonoid extraction from these Passiflora species is maceration with $75 \%$ ethanol for $P$. edulis and $50 \%$ ethanol for $P$. alata.
\end{abstract}

Revista Brasileira de Farmacognosia Brazilian Journal of Pharmacognosy 22(5): 1119-1129, Sep./Oct. 2012

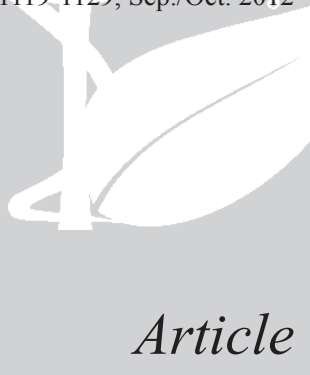

Received 20 Jun 2011

Accepted 10 Jan 2012

Available online 20 Mar 2012

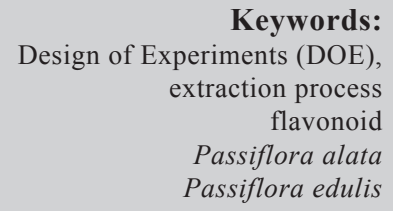

ISSN 0102-695X http://dx.doi.org/10.1590/S0102 $695 \times 2012005000036$

\section{Introduction}

The Passifloraceae family is distinguished from other plants used in native Brazilian folk medicine due to its extensive use in the treatment of a wide variety of diseases. The Passiflora genus is comprised of about 400 species and is the most important genus in this family. Passifloraceae is represented by approximately twenty genera and 600 species that are distributed mainly in tropical and subtropical regions, many in Brazil. There are four genera (Ancistrothyrsus Harms, Dilkea Mast., Mitostemma Mast., Passiflora L.) localized to Brazil (Cervi et al., 2010), including about 137 species and a wide geographical distribution; about 88 species are native to Brazil. Most of these species are related to the Passiflora genus, and products derived from these plants are internationally recognized as herbal medicines (Carlini, 2003).

In Brazil, species of the Passiflora genus are known as "maracujá". Passiflora alata Curtis and
Passiflora edulis Sims are the "passion fruit" species currently cultivated at a commercial scale. They are mainly produced in the states of Bahia and São Paulo, and their fruit is consumed in natura or in juices and ice creams (Veras et al., 2000; Petry et al., 2001, IBGE, 2008). These species are used in several pharmaceutical preparations that are registered by the Brazilian regulatory agency "Agência Nacional de Vigilância Sanitária".

In $1788, P$. alata, which is native to Brazil, was originally described as Passiflora alata Curtis by the Botanical Magazine (Curtis, 1788; Bernacci, et al., 2003). This species is cited in four editions of the Brazilian Pharmacopeia (Pharmacopeia dos Estados Unidos do Brasil, 1926; Farmacopéia dos Estados Unidos do Brasil, 1959; Farmacopéia Brasileira, 1977; 2010). Recently, a bibliographic review of $P$. alata was reported by Noriega et al. (2011). Passiflora edulis has several common names, such as sour passion fruit. At the taxonomic level, Passiflora edulis Sims must be used for any plant and color of sour passion fruits (Bernacci et al., 2008). 
In the past decade, many Brazilian researchers have investigated the phytochemistry and pharmacology of $P$. alata and $P$. edulis leaves. It was reported that both leaves extracts present expressive amount of flavonoids (Barbosa et al., 2008), which could explain their antioxidant activity in vitro, ex vivo (Rudnicki et al., 2007a) and hepatoprotective effects described (Rudnicki, et al., 2007b). More recently, Ripa et al. (2009) verified the antioxidant, antibacterial and cytotoxic activities of $P$. edulis. Oxidative stress impairs the homeostasis and leads to excessive reactive oxygen/nitrogen species production. Therefore researchers are focused on antioxidants that may help to reduce oxidative stress level and to treat diseases where overproduction of those species are observed (Huk-Colega, 2011).

The first report of the pharmacological activity of P. alata came from Oga et al. (1984). They found that an extract of $P$. alata leaves increased the induction of sleep by pentobarbital in rats (Oga et al., 1984). The anxiolytic activity of extracts of $P$. alata and $P$. edulis leaves was evaluated using the elevated plus-maze test (Petry et al., 2001; de Paris et al., 2002; Reginatto et al., 2006).

The use of $P$. edulis leaves extract resulted in improved wound healing (Gonçalves-Filho et al., 2006; Gomes et al., 2006) and the inhibition of parasite growth (Bezerra et al., 2006). The aqueous extract of the root was effective against three types of viruses (Müller et al., 2007). The mechanism of the anti-inflammatory effect of aqueous lyophilized extract obtained from leaves of $P$. edulis in the mouse model of pleurisy was investigated by Montanher et al. (2007). The antiulcer activity of $P$. alata was evaluated at doses of 100, 200 and $400 \mathrm{mg} / \mathrm{kg}$ of extract (Wasicky, 2007).

Pharmaceutical processes were investigated by Runha et al. (2001). In this study, a process was developed for the production of dry passion flower extract using spouted beds as drying equipment. In another study, the performance of the spray and spouted bed dryer, and the physicochemical properties of the products that resulted from the drying of the hydro-alcoholic extracts of P. alata were comparatively evaluated by Oliveira et al. (2006). Linden et al. (2000) described the formulation of tablets containing high proportions of spray-dried extracts (SDE) from $P$. edulis leaves.

The design of experiments (DOE) methodology offers the maximum return in terms of information about the interplay of multiple factors while requiring the minimum investment (Martinello et al., 2006; Noriega et al., 2008).

In recent years, interest in herbal medicinal products, especially in the field of dermatology and cosmetics, has risen enormously. Modern phytopharmaceutics as well as phytocosmetics require standardized defined extracts from the herbal matrix.
Several researchers have studied the extraction process applied to medicinal plants. The purpose of these studies has been the development of an adequate methodology to evaluate the influence of extractive parameters on active markers contents obtained from herbal drugs (Liu et al., 2000; Hinneburg \& Neubert, 2005; Noriega et al., 2005; Souza et al., 2007; Silva et al., 2009).

The objective of this paper was to evaluate, by determination of total flavonoid content, the influence of ethanol concentration and extraction methods (maceration versus percolation) on the preparation of Passiflora alata Curtis and Passiflora edulis Sims extracts. The results were maximized using the design of experiments (DOE) and the samples with the highest flavonoid content were submitted to ORAC assay to determine their antioxidant activity.

\section{Materials and Methods}

\section{Chemicals and reagents}

All chemicals were of analytical reagent-grade quality, and the anhydrous rutin was acquired from Sigma Aldrich $^{\circledR}$. Ethanol, methanol, acetic acid and anhydrous aluminum trichloride were purchased from Labsynth, Brazil. Bidistilled water was used for all experiments.

\section{Plant material}

Leaves from Passiflora edulis Sims and P. alata Curtis, Passifloraceae, were provided by the Instituto Agronômico de Campinas from a BAG (bank active germplasm) located in Monte Alegre do Sul, SP (750 $\mathrm{m}$ high) collected in February 2010. Two exsiccates deposited in the herbarium of IAC, Instituto Agronômico, under $\mathrm{n}^{\circ} 37119$ and $\mathrm{n}^{\circ} 52798$ for $P$. edulis and P. alata Curtis, respectively.

\section{Passiflora extracts preparation}

The aerial parts from the two Passiflora species were processed separately. Figure 1 illustrates the processes as a flowchart. The leaves were washed, cut and dried in a stove with circulating air at a temperature below $50{ }^{\circ} \mathrm{C}$ for $72 \mathrm{~h}$. The dried leaves were then triturated in a hammer mill (Thomas, PA, USA) to obtain particles between 0.5 and $1.0 \mathrm{~mm}$. Extractions were carried out using a ratio of 1:10 for plant to solvent mass at room temperature. The alcohol of the solutions was evaporated under a reduced pressure in a Büchi rotary evaporator (model B-480) at $50{ }^{\circ} \mathrm{C}$. The remaining aqueous extracted material was lyophilized in an Edwards lyophilizer (Brazil) at 0.9 mbar (-40 $\left.{ }^{\circ} \mathrm{C}\right)$. The total flavonoids content of each extract $(5$ and $2.5 \mathrm{mg} / \mathrm{mL}$ ) compared to a compensation solution 
were measured spectrophotometrically in triplicate at $427 \mathrm{~nm}$ based upon the formation of a complex with $2 \%$ $\mathrm{AlCl}_{3}$ (Pozzi, 2007; Chabariberi et al., 2009).

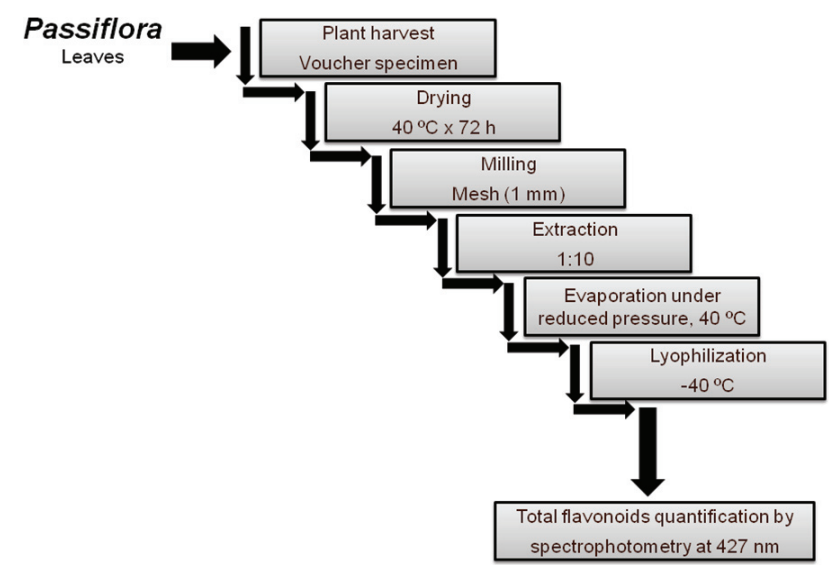

Figure 1. Flowchart of the extract preparation process.

\section{Experimental design and statistical analysis}

Experiments where the factors are the ingredients or the components of a mixture are called mixture experiments (ME). In mixture experiments, the choice of component levels is not independent. The response is assumed to depend only on the relative proportions of the components rather than the total amount in the mixture. In the standard mixture designs, the proportions of the ingredients can vary between 0 and 1 and must sum up to unity. (Cornell, 2002; Adeyeye, 2008).

In certain situations, there may be factors other than the mixture components to affect the characteristics of the mixture. These factors are called process variables, which are frequently included in the experiment as factorial designs. Therefore, it is of interest to determine not only the optimum mixture components proportions, but also the process variables' optimum levels. In this context, the experiments conducted are called mixtureprocess experiments (MPE). (Cornell, 1990; Dal Bello \& Viera, 2011)

The design of experiments (DOE) and statistical analysis were performed employing Design Expert software (Version 8, 2010, Stat-Ease Inc., Minneapolis, MN, USA). This software offers the option of planning ME including process variables. Factors and levels were selected on the basis of the extraction date reported in the literature and based on preliminary studies carried out before implementing the experimental design.

The problem of flavonoid extraction from Passiflora was treated as an experiment with mixture including one categorical process variable. The components of binary mixture are: ethanol (component $\mathrm{A})$ and water (component $\mathrm{B}$ ); the categorical process variable: extraction method (factor $\mathrm{C}$ ) was varied at two levels: (+1) maceration and (-1) percolation. All other processing variables were kept invariant throughout the study. The dependent variable (response) was total flavonoid content for both species. The experiment was performed with replications on the central point, the lowest level and the highest level. The experimental matrix was designed and tested by us and suggested a quadratic model with fourteen runs. The general combined model with the inclusion of process variables is represented in a matrix form as Table 1 .

Table 1. Design of experiments matrix for flavonoids extraction from Passifloras, considering alcohol proportion and extraction method as variables in mixture-process experiments (MPE).

\begin{tabular}{ccccc}
\hline \multicolumn{5}{c}{ Design of Experiments Matrix } \\
\hline \multirow{2}{*}{ Run } & $\begin{array}{c}\text { Component } \\
\text { A: Ethanol }\end{array}$ & $\begin{array}{c}\text { Component } \\
\text { B: Water }\end{array}$ & Blend Type & $\begin{array}{c}\text { Factor C: } \\
\text { Method }\end{array}$ \\
\hline 1 & 0.50 & 0.50 & Binary & Percolation \\
2 & 0.75 & 0.25 & Quarter & Maceration \\
3 & 1.00 & 0.00 & Pure & Maceration \\
4 & 0.00 & 1.00 & Pure & Maceration \\
5 & 0.50 & 0.50 & Binary & Maceration \\
6 & 0.00 & 1.00 & Pure & Percolation \\
7 & 1.00 & 0.00 & Pure & Percolation \\
8 & 0.00 & 1.00 & Pure & Percolation \\
9 & 1.00 & 0.00 & Pure & Maceration \\
10 & 0.25 & 0.75 & Quarter & Percolation \\
11 & 0.00 & 1.00 & Pure & Maceration \\
12 & 1.00 & 0.00 & Pure & Percolation \\
13 & 0.75 & 0.25 & Quarter & Percolation \\
14 & 0.25 & 0.75 & Quarter & Maceration \\
\hline
\end{tabular}

Evaluation of spectrophotometric methodology for quantification of total flavonoids (rutin)

The use of markers in the quality control of several medicinal plants has become essential for the standardization of analytical methods, especially in the quantification of plant constituents. Rutin is a bioflavonoid that occurs in many plants and is known for its antioxidant activity. It is one of the substances most used as marker in spectrophotometry because of its low price and wide availability. However, there are several publications that use different types of rutin solutions, and there is no agreement on a standard rutin.

To evaluate the influence of the type and concentration of alcohol on flavonoid content quantification, a similar experimental matrix was performed (Table 1 and Figure 2) and augmented with two central points (16 runs). The components of binary mixture are: alcohol (component A) and water (component B); the categorical process variable: type of solvent (factor C) was varied at two levels: $(+1)$ methanol 
and (-1) ethanol. The dependent variable (response) was the absorbance of 16 the rutin solutions $(0.5 \mathrm{mg} / \mathrm{mL})$.

\section{Total flavonoid content}

Pozzi (2007) and Chabariberi et al. (2009) reported on a modification of the spectrometric procedures originally described in the French Pharmacopoeia for the analysis of Passiflora incarnata L., Passifloraceae, flavonoids and proposed its application in the determination of total flavonoids from $P$. edulis and $P$. alata leaves. In these studies, the results obtained by a spectrometric procedure were compared to those obtained by high performance liquid chromatography (HPLC-UV). The authors demonstrated complete compatibility between the modified French Pharmacopoeia (spectrometric) and HPLC-UV methods (Pozzi, 2007; Chabariberi et al., 2009).

On the other hand, in our laboratory, we adapted this spectrometric method to a total volume of $250 \mu \mathrm{L}$. Each one of the extracts was quantified in solutions of $5 \mathrm{mg} / \mathrm{mL}$ and $2.5 \mathrm{mg} / \mathrm{mL}$ against a compensation solution in triplicate. Briefly, stock solution (SS) was made with Passiflora extracts in 50\% ethanol (EtOH). A volume of $20 \mu \mathrm{L}$ of $2 \% \mathrm{AlCl}_{3}(\mathrm{w} / \mathrm{v})$ in ethanol was added to $20 \mu \mathrm{L}$ of SS; the volume was increased to 250 $\mu \mathrm{L}$ using an ethanolic solution of $0.5 \%$ acetic acid (v/v) (probe solution (PS)). At the same time, $20 \mu \mathrm{L}$ of SS were brought to a volume of $250 \mu \mathrm{L}$ with a methanol/acetic acid solution (contrast solution (CS)). The absorbance of PS against CS was measured at $427 \mathrm{~nm}$ after $30 \mathrm{~min}$ using a microplate Synergy-BioTek Reader. The result, expressed as the percentage of total flavonoids content (TFC), was calculated as rutin using the calibration curve equation. The results represent the average of three determinations

\section{Antioxidant activity using the ORAC method}

We evaluated the antioxidant activities of the Passiflora extracts with the highest flavonoids content. In ORAC methodology, an azo initiator (AAPH - 2,2'azobis(2-amidino-propane) dihydrochloride) at $37{ }^{\circ} \mathrm{C}$ abstracts hydrogen from sodium fluorescein, which reduces fluorescence. In the presence of an antioxidant, the fluorescence decrease is inhibited.

Briefly, an extract was added to hexane, mixed for $2 \mathrm{~min}$. and centrifuged at $2000 \mathrm{x} \mathrm{g}$ for $3 \mathrm{~min}$. One milliliter of the organic (hexane) layer was removed and dried under flowing nitrogen for the lipophilic ORAC assay. The dried material was dissolved in acetone and diluted with 7\% RMCD (randomly methylated $\beta$-cyclodextrin) solution (50\% acetone $/ 50 \%$ water, $(\mathrm{v} / \mathrm{v}))$. For the hydrophilic assay, the remaining extract was dissolved in 50\% ethanol and diluted with $75 \mathrm{mM}$ phosphate buffer ( $\mathrm{pH} 7.0)$.

In a 96-well microplate, $25 \mu \mathrm{L}$ of the diluted sample or standard $\left(\right.$ Trolox $\left.^{\circledR}\right)$ was combined with 150 $\mu \mathrm{L}$ of fluorescein solution $(40 \mathrm{nM}$ in $75 \mathrm{mM}$ phosphate buffer, $\mathrm{pH}$ 7.0). The microplate was incubated at $37{ }^{\circ} \mathrm{C}$ for $30 \mathrm{~min}$. The reaction was initiated by the addition of $25 \mu \mathrm{L}$ of AAPH (153 mM in $75 \mathrm{mM}$ phosphate buffer, $\mathrm{pH}$ 7.0) followed by shaking at maximum intensity for $10 \mathrm{~s}$.

Fluorescence was monitored kinetically, with data collected every minute. A Synergy ${ }^{\mathrm{TM}}$ HT MultiDetection Microplate Reader (Winooski, VT, USA) was used with a $485 \mathrm{~nm} / 20 \mathrm{~nm}$ bandpass excitation filter and a $528 \mathrm{~nm} / 20 \mathrm{~nm}$ bandpass emission filter. Fluorescence was measured from the bottom at a sensitivity setting of 60 (Ou et al., 2001; Prior et al., 2003).

\section{Results and Discussion}

In recent years, there has been an increasing interest worldwide in the use of alternative/herbal medicines for the prevention and treatment of various illnesses. However, quality-related problems (lack of consistency, safety and efficacy) seem to be overshadowing the potential genuine health benefits of various herbal products (Hui, 2002). Modern phytopharmaceutics require standardized, defined extracts from the herbal matrix. The extraction procedure is important because the extraction conditions determine the quality and the yield of the individual constituents (Hinneburg \& Neubert, 2005). Selection of an appropriate extraction method will depend upon the type of herb and compounds, the amount of herbal material available and the amount of compound required (Wang et al., 2003).

\section{Evaluation of a spectrophotometric methodology for quantification of total flavonoids (rutin)}

The use of validated methods in the chemical standardization of botanicals and herbal preparations will enhance the quality of the products, assist in pharmacological studies, perform credible clinical trials and propel the move towards evidence-based medicine (Ong, 2004). The results of the experiments were interpreted using Design Expert software (Version 8, 2010, Stat-Ease Inc., Minneapolis, MN, USA). Statistical analysis of the data suggested a model significant with model F-value of 22.06, $p$-value $<0.0001$ and R-Squared $=0.8465$. In this case Linear Mixture Components, AC are significant model terms. The main effects and interactions are displayed as polynomial equations 1a and $1 \mathrm{~b}$ :

Final equation in terms of actual components and actual factors: 
Rutin absorbance in methanol $=+0.66 *$ Alcohol $(\%)$ $-0.15 *$ Water (\%) Eq. (1a)

Rutin absorbance in ethanol $=+0.28 *$ Alcohol $(\%)+0.16^{*}$ Water (\%) Eq. (1b)

In the equations, the high coefficient for methanol (0.66) indicates that a higher methanol proportion increased the absorption values from the rutin solutions, whereas the absorption values remained practically unaltered with larger ethanol proportions (coefficient 0.28). These results could be correlated with the solubility studies reported by $\mathrm{Zi}$ et al. (2007) and Peng (2009). By a saturation method, these authors determined the solubilities of rutin in water, methanol and ethanol, which are typically used in laboratories and related industries.

Calibration curve gave the equation $(\mathrm{r} 2=0.995)$ :

Absorbance $=0.001 *$ Concentration -0.030 Eq. (2)

Experimental design and statistical analysis of the Passiflora extract preparation

The aim of this paper was to systematically evaluate the influence of extraction parameters on the extract quality. Formulations of Mixture Experiments (ME) are commonly found in chemical, pharmaceutical and food industries, as well as in other industrial segments. Therefore, a mixture-process experiments (MPE) design was used. In terms of yield, the components of binary mixture are: ethanol (component $\mathrm{A}$ ) and water (component B) is the most important factors that influence extraction efficacy. No important differences were observed for the categorical process variable: extraction method (factor C). Table 2 summarizes the results of the response studied from fourteen extractions.

\section{Passiflora alata Curtis}

In this study, the extraction efficiencies of percolation and maceration for the extraction of flavonoids from P. alata and P. edulis were evaluated. Percolation is a method preconized by the Brazilian Pharmacopeia for P. alata, and maceration is a simpler method that could be used at the industrial scale. Mixtures of ethanol and water were chosen as nontoxic and environmentally friendly solvents, have been shown to be effective in the extraction of flavonoids (Hinneburg \& Neubert, 2005).

The ANOVA suggested a quadratic model, with a sequential $p$-value of 0.0028 and $\mathrm{R}$-Squared $=0.8615$ Table 3. The results of the extraction total flavonoids (TF) concentration using experiment with mixture including a categorical process variable: extraction method are displayed as a mathematical model (Eqs. 3.1 and 3.2) and in a graphical form (Figure 2).

The Model F-value of 9.95 implies the model is significant. There is only a $0.28 \%$ chance that a "Model F-Value" this large could occur due to noise. Values of "Prob > F" less than 0.0500 indicate model terms are significant. In this case Linear Mixture Components, $\mathrm{AB}$ are significant model terms. Factor $\mathrm{C}$ is not significant. Taking into account that, extraction method had only a

Table 2. Results of Passiflora extraction design of experiments (DOE) matrix measured by total flavonoids content (TFC), expressed as $\mu \mathrm{g} / \mathrm{mL}$ and $(\% \mathrm{w} / \mathrm{w})$ related to the dried plant material.

\begin{tabular}{cccccc}
\hline \multirow{2}{*}{ Run } & \multirow{2}{*}{ Variables } & \multicolumn{2}{c}{ Passiflora alata } & \multicolumn{2}{c}{ Passiflora edulis } \\
\cline { 2 - 6 } & & $\mathrm{TFC}(\mu \mathrm{g} / \mathrm{mL})$ & $\mathrm{TFC}(\% \mathrm{w} / \mathrm{w})$ & $\mathrm{TFC}(\mu \mathrm{g} / \mathrm{mL})$ & $\mathrm{TFC}(\% \mathrm{w} / \mathrm{w})$ \\
\hline 1 & $50(\mathrm{P})$ & $110.5 \pm 0.008$ & 4.23 & $136.5 \pm 0.005$ & 6.68 \\
2 & $75(\mathrm{M})$ & $204.5 \pm 0.011$ & 4.21 & $294.3 \pm 0.028$ & 9.14 \\
3 & $100(\mathrm{M})$ & $233.5 \pm 0.024$ & 3.21 & $327.4 \pm 0.007$ & 6.11 \\
4 & $0(\mathrm{M})$ & $211.5 \pm 0.022$ & 2.21 & $334.1 \pm 0.031$ & 2.73 \\
5 & $50(\mathrm{M})$ & $144.5 \pm 0.025$ & 4.67 & $165.2 \pm 0.018$ & 6.55 \\
6 & $0(\mathrm{P})$ & $118.5 \pm 0.048$ & 2.89 & $146.2 \pm 0.005$ & 3.47 \\
7 & $100(\mathrm{P})$ & $168.5 \pm 0.037$ & 3.37 & $292.5 \pm 0.005$ & 5.85 \\
8 & $0(\mathrm{P})$ & $137.5 \pm 0.023$ & 2.75 & $173.4 \pm 0.010$ & 3.30 \\
9 & $100(\mathrm{M})$ & $210.5 \pm 0.02$ & 4.29 & $456.8 \pm 0.016$ & 5.36 \\
10 & $25(\mathrm{M})$ & $177.5 \pm 0.02$ & 3.55 & $186.2 \pm 0.006$ & 3.7 \\
12 & $0(\mathrm{M})$ & $172.5 \pm 0.005$ & 2.37 & $178.6 \pm 0.010$ & 2.92 \\
13 & $100(\mathrm{P})$ & $160.5 \pm 0.028$ & 4.09 & $305.6 \pm 0.028$ & 5.89 \\
\end{tabular}

Variables: Percent of ethanol: 0, 25, 50, 75 and 100 (\%). Extraction Method: (P) Percolation and (M) Maceration. TFC: Total Flavonoids Content. SD: Standard Deviation. 
Table 3. ANOVA for Combined Linear x Main effects Model for Passiflora alata extraction.

\begin{tabular}{ccccccc}
\hline Source & Sum of Squares & df & Mean Square & F Value & $p$-value Prob $>$ F & Significant \\
\hline Model & 18032.39 & 5 & 3606.48 & 9.95 & 0.0028 & 0.0012 \\
Linear Mixture & 8742.25 & 1 & 8742.25 & 24.12 & 0.0012 \\
AB & 8603.48 & 1 & 8603.48 & 23.74 & 0.8693 \\
AC & 10.46 & 1 & 10.46 & 0.029 & 0.2098 \\
BC & 673.86 & 1 & 673.86 & 1.86 & 0.4432 & \\
ABC & 235.83 & 1 & 235.83 & 0.65 & 0.8392 & Not significant \\
Residual & 2899.04 & 8 & 362.38 & & \\
Lack of Fit & 736.54 & 4 & 184.14 & 0.34 & & \\
Pure Error & 2162.50 & 4 & 540.63 & & & \\
Cor Total & 20931.43 & 13 & & &
\end{tabular}

slight effect on the extraction process, the equations are showed separately for each method, Eq. (3.1) and Eq. (3.2).

Final equation in terms of actual components and actual factors:

Extraction method: maceration. P. alata: Total flavonoids $(\mathrm{mg} / \mathrm{mL})=+186.43 * \mathrm{~A} \%+113.09 * \mathrm{~B} \%+275.48 * \mathrm{~A} \% * \mathrm{~B} \%$ Eq. (3.1)

A: ethanol; B: water

Extraction method: percolation. P. alata: Total flavonoids $(\mathrm{mg} / \mathrm{mL})=+189.56 * \mathrm{~A} \%+138.22 * \mathrm{~B} \%+197.22 * \mathrm{~A} \% * \mathrm{~B} \%$ Eq. (3.2)

A: ethanol; B: water

These equations and the graphical results indicate that proportion of components $\mathrm{A}$ and $\mathrm{B}$ in mixture is the main factor involved in significantly increasing flavonoid extraction. In general terms, increasing the ethanol proportion between $50-75 \%$ in the binary mixture of ethanol and water, the flavonoids extraction is significantly increased.

\section{Passiflora edulis Sim}

ANOVA suggested a cubic model, with a sequential $p$-value $<0.0001$ and $\mathrm{R}$-Squared $=0.9819$ (Table 4). The results of the extraction total flavonoids (TF) concentration using experiment with mixture including a categorical process variable: extraction method are displayed as a mathematical model (Eqs. 4.1 and 4.2) and in a graphical form (Figure 3).

The Model F-value of 100.56 implies the model is significant. There is only a $0.01 \%$ chance that a "Model F-Value" this large could occur due to noise. Values of "Prob > F" less than 0.0500 indicate model terms are significant. In this case Linear Mixture Components, $\mathrm{AB}$, $\mathrm{AB}(\mathrm{A}-\mathrm{B})$ are significant model terms. Factor $\mathrm{C}$ is not
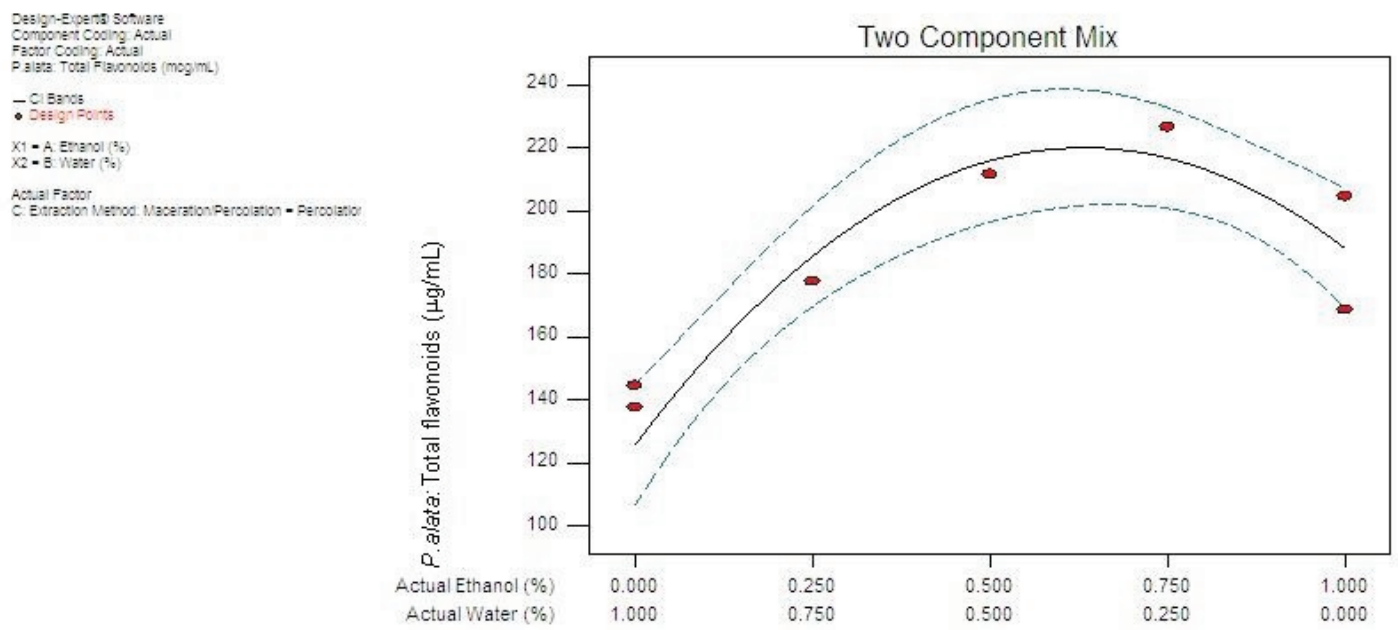

Figure 2. Graphical result of the matrix DOE for Passiflora alata percolation extraction. 
Table 4. ANOVA for Combined Linear x Main effects Model for Passiflora edulis extraction.

\begin{tabular}{ccccccc}
\hline Source & Sum of Squares & df & Mean Square & F Value & p-value Prob $>$ F & Significant \\
\hline Model & 1.340 .105 & 7 & 19136.67 & 100.56 & $<0.0001$ & $<0.0001$ \\
Linear Mixture & 70136.69 & 1 & 70136.69 & 368.55 & $<0.0001$ \\
AB & 31014.48 & 1 & 31014.48 & 162.97 & 0.7137 \\
AC & 28.17 & 1 & 28.17 & 0.15 & 0.1017 \\
BC & 709.41 & 1 & 709.41 & 3.73 & 0.1873 \\
ABC & 421.49 & 1 & 421.49 & 2.21 & $<0.0001$ \\
AB(A-B) & 31496.32 & 1 & 31496.32 & 165.50 & 0.2821 \\
ABC(A-B) & 265.65 & 1 & 265.65 & 1.40 & \\
Residual & 1141.83 & 10 & 190.31 & & 0.4777 \\
Lack of Fit & 352.67 & 6 & 176.33 & 0.89 & Not significant \\
Pure Error & 789.17 & 4 & 197.29 & & \\
Cor Total & 1.351 .105 & 13 & 31496.32 & & \\
\hline
\end{tabular}
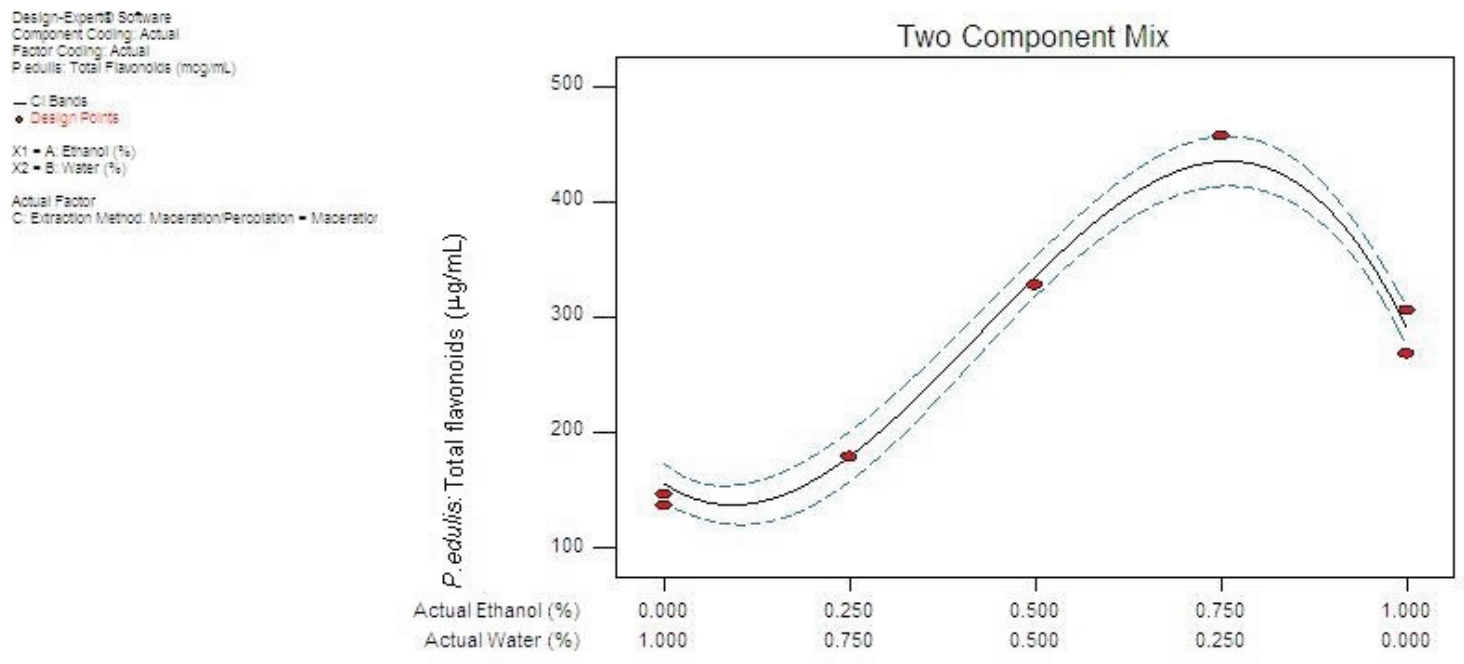

Figure 3. Graphical result of the matrix DOE for Passiflora edulis maceration extraction.

significant.

Final equation in terms of actual components and actual factors:

Extraction method: maceration. P. edulis: Total flavonoids $(\mathrm{mg} / \mathrm{mL})=+287.78 \times \mathrm{A} \%+142.43 \times \mathrm{B} \%+501.05 \times \mathrm{A} \% \times$ $\mathrm{B} \%+1003.93 \times \mathrm{A} \% \times \mathrm{B} \% \times(\mathrm{A} \%-\mathrm{B} \%) \quad$ Eq. (4.1)

A: ethanol; B: water

Extraction method: percolation. P. edulis: Total flavonoids $(\mathrm{mg} / \mathrm{mL})=+293.069 \times \mathrm{A} \%+168.97 \times \mathrm{B} \%+396.43 \times \mathrm{A} \% \times$ $\mathrm{B} \%+1003.93 \times \mathrm{A} \% \times \mathrm{B} \% \times(\mathrm{A} \%-\mathrm{B} \%) \quad$ Eq. (4.2)

A: ethanol; B: water

The cubic model suggested for the Passiflora edulis Sim flavonoid extraction Eqs. (4.1 and 4.2) and Figure 3 is a bit more complicated than the Passiflora alata Curtis quadratic model. In general terms, increasing the ethanol proportion until of ethanol $75 \%$ in the binary mixture, the flavonoids extraction is significantly increased. However, flavonoids extraction decreased when $100 \%$ ethanol was used.

ANOVA indicated no effect due to the extraction method used in the flavonoid extraction process for both species. Therefore, the results obtained indicated that these two traditional extraction methods could effectively extract flavonoids from both medicinal plants. This phenomenon could be explained by solvent selectivity and solvent saturation of compounds from vegetal drugs. These results confirm the necessity of standardization for plant material. For this reason, the Passiflora samples were cultivated, identified and provided by the Instituto Agronômico de Campinas from a BAG (bank active germplasm).

There were significant differences in flavonoids extraction between the two Passiflora species studied, and the differences depended on the ethanol concentration 
used. These results corroborate the assertion of Wang et al. (2003). These authors claim the chemical natures of herb constituents differ considerably between species. The same herbal extracts may vary depending on harvest season, plant origin, drying process and other factors. To illustrate the interpretation of extraction models for $P$. alata (quadratic) and P. edulis (cubic), we used a simplified graph for both models on the same scale for the extraction method by maceration (Figure 4).

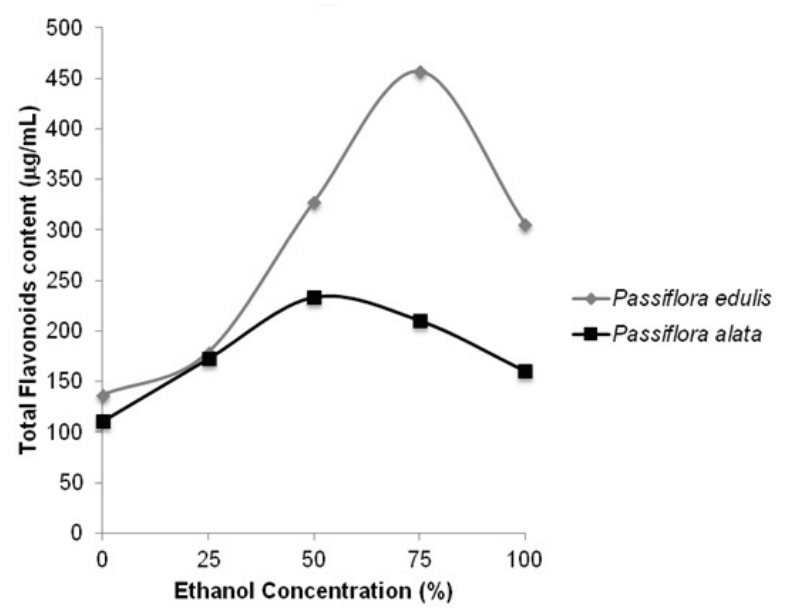

Figure 4. Schematic and comparative representation of the DOE graphical results for flavonoids maceration extraction from $P$. alata and $P$. edulis.

Taking flavonoid solubility into account, the alcohol percentage was varied from 0 to $100 \%$. As illustrated in Figure 4, the flavonoids content was similar for both species at lower ethanol concentrations $(0-25 \%)$. Between 50 and $75 \%$, flavonoid extraction increased significantly when the ethanol proportion was increased for $P$. edulis, but remain practically unaltered for $P$. alata. Maximum flavonoid extraction was achieved with $75 \%$ ethanol for $P$. edulis. At this concentration, evaluation of the flavonoid content indicated that the $P$. edulis extract $(9.14 \% \mathrm{w} / \mathrm{w})$ contained twice the flavonoid content of $P$. alata $(4.21 \% \mathrm{w} / \mathrm{w})$. These results have been corroborated by Petry et al. (2001) and De Paris et al. (2002). On the other hand, a significant decrease in flavonoids extraction was observed when increasing to $100 \%$ ethanol for $P$. alata. $P$. edulis also displayed a significant diminution of flavonoids extraction. However, extraction from $P$. edulis was higher than $P$. alata at the same ethanol concentration.

\section{Antioxidant activity using the ORAC method}

Flavonoids are used for the prevention and cure of various diseases which is mainly associated with free radicals. Flavonoids acts as an antioxidant in biological systems and scavenge the free radicals thereby increasing the antioxidant defence in the body. The Passiflora extracts with highest flavonoids content (P. edulis at $75 \%$ ethanol and P. alata at 50\% ethanol) were evaluated for antioxidant capacity by the ORAC method, the results are displayed in Table 5.

Table 5. Antioxidant activity of Passiflora extracts with higher flavonoids content.

\begin{tabular}{lc}
\hline \multicolumn{1}{c}{ Extract } & $\begin{array}{c}\text { Antioxidant activity } \\
(\mu \mathrm{mol} \text { eq. Trolox/g) }\end{array}$ \\
\hline Passiflora alata (hydrophilic fraction) & $1109 \pm 62$ \\
Passiflora alata (lipophilic fraction) & below the limit of detection \\
Passiflora edulis (hydrophilic fraction) & $1971 \pm 113$ \\
Passiflora edulis (lipophilic fraction) & $63 \pm 3$ \\
\hline
\end{tabular}

In our study, it was possible to verify that $P$. edulis was almost twice more active than P. alata, being these values considered moderate compared to other extracts described in the literature (Ou et al., 2001) and to Trolox standard $(4000 \mu \mathrm{mol} / \mathrm{g})$.

Considering the flavonoids concentration found to the extracts, we can correlate the better antioxidant activity with the highest content of rutin (TFC) in $P$. edulis extract $(9.14 \% \mathrm{w} / \mathrm{w})$. This finding corroborates the results presented by Barbosa et al., 2008.

As far as we know this is the first report of antioxidant activity of $P$. alata and P. edulis leaves extract by ORAC method. The comparison between the data from other methods previously reported is not possible because the values of the reference substance were not clearly presented or were absent (Rudnicki et al., 2007a; Ferreres et al., 2007).

\section{Conclusions}

The use of design of experiments (DOE) in extraction of plant material will play a central role in the development and modernization of processes for preparations of standardized phytotherapics. In our study, the experimental design conducted is called mixture-process experiments (MPE), the efficiencies of two extraction methods used in phytotherapy medicine (percolation and maceration) and binary solvent mixtures of ethanol-water concentrations were evaluated for flavonoids extractions from Passiflora alata Curtis and Passiflora edulis Sims.

The results obtained indicated that these two traditional extraction methods could effectively extract antioxidants flavonoids from medicinal plants. We recommended the use of maceration because is a simple, rapid and environmentally friendly extraction method.

In regard to influence of mixture (ethanolwater), ANOVA suggest a cubic model for $P$. edulis extraction and a quadratic model for $P$. alata. These 
results indicated that proportion of components ethanol and water in mixture is the main factor involved in significantly increasing flavonoid extraction.

The evaluation of antioxidant activity of the extract by ORAC method showed that $P$. edulis displays twice the antioxidant activity than $P$. alata. The optimized conditions for flavonoid extraction from these Passiflora species is maceration with $75 \%$ ethanol for P. edulis and $50 \%$ ethanol for P. alata. In this context, mixture-process experiments (MPE) can be extended to evaluation of the extraction process of others medicinal plants.

\section{Acknowledgements}

CAPES/PRODOC, Pró-Reitoria de Pesquisa USP (IC), Santander (IC) and FUNDAG. The authors wish to thank Dra. Maria Elena Santos Taqueda (Escola Politécnica-USP) for her helpful assistance in the interpretation of results of Design of Experiments (DOE).

\section{References}

Adeyeye AD, Oyawale FA 2008. Mixture experiments and their applications in Welding Flux Design. J Braz Soc of Mech Sci \& Eng 30: 319-326.

Barbosa PR, Valvassori SS, Bordignon CL, Kappel VD, Martins MR, Gavioli EC, Quevedo J, Reginatto FH 2008. The aqueous extract of Passiflora alata and Passiflora edulis reduce anxiety-related behaviors without affecting memory process in rats. $J$ Med Food 11: 282-288.

Bernacci LC, Meletti LMM, Soares-Scott MD 2003. Maracujádoce: o autor, a obra e a data da publicação de Passiflora alata (Passifloraceae). Rev Bras Frutic 25: 355-356.

Bernacci LC, Soares-Scotti MD, Junqueira NTV, Passos IRS, Meletti LMM 2008. Passiflora edulis Sims: the correct taxonomic waay to cite the yellow fruit (and of other colors). Rev Bras Frutic 30: 566-576.

Bezerra JL, Costa GC, Lopes TC, Carvalho ICDS, Patrício FJ, Sousa SM, Amaral FMM, Rebelo JMM, Guerra RNM, Ribeiro MNS, Nascimento FRF 2006. Avaliação da atividade leishmanicida in vitro de plantas medicinais. Rev Bras Farmacogn 16: 631-637.

Carlini EA 2003. Plants and the central nervous system. Pharmacol Biochem Behav 75: 501-512.

Cervi AC, Milward-de-Azevedo MA, Bernacci LC 2010. Passifloraceae. http://floradobrasil.jbrj.gov.br, accessed in May 2010.

Chabariberi RAO, Pozzi ACS, Zeraik ML, Yariwake JH 2009. Determinação espectrofotométrica dos flavonóides das folhas de Maytenus (Celastraceae) e de Passiflora (Passifloraceae) e comparação com método CLAE-UV. Rev Bras Farmacogn 19: 860-864.

Cornell JA 1990. The inclusion of process variables in mixture experiments. In Cornell JA (org.) How to run mixture experiment for product quality. Milwaukee: ASQ, p.7988.

Cornell JA. 2002. Experiments with Mixtures: Designs, Models and the Analysis of Mixture Data. New York: John Wiley \& Sons.

Curtis W 1788. The botanical magazine, or, flower-garden displayed. Londres: Couchman and Fry.

Dal Bello LHA, Vieira AFC 2011. Optimization of a product performance using mixture experiments including process variables. J Appl Stat 38: 1701-1715.

De-Paris F, Petry RD, Reginatto FH, Gosmann G, Quevedo J, Salgueiro JB, Kapczinski F, González-Ortega G, Schenkel EP 2002. Pharmacochemical study of aqueous extracts of Passiflora alata Dryander and Passiflora edulis Sims. Acta Farm Bonaer 21: 5-8.

Farmacopéia Brasileira 1977. São Paulo: Organização Andrei Editora S.A.

Farmacopéia Brasileira/Agência Nacional de Vigilância Sanitária. Brasília: Anvisa 2010. http://www.anvisa. gov.br/hotsite/cd_farmacopeia/index.htm, Accessed Mar, 2011.

Farmacopéia dos Estados Unidos do Brasil 1959. São Paulo: Gráfica Siqueira.

Ferreres F, Sousa C, Valentão P, Andrade PB, Seabra RM, GilIzquierdo 2007. New C-deoxyhexosyl flavones and antioxidant properties of Passiflora edulis leaf extract. J Agric Food Chem 55: 10187-10193.

Gomes CS, Campos ACL, Torres OJM, De Vasconcelos PRL, Moreira ATR, Tenório SB, Tâmbara, EM, Sakata K, Júnior HM, Ferrer ALS 2006. Efeito do extrato de Passiflora edulis na cicatrização da parede abdominal de ratos: estudo morfológico e tensiométrico. Acta Cir Bras 21: 9-16.

Gonçalves-Filho A, Torres OJM, Campos ACL, Tambara-Filho R, Rocha LCA, Lunedo SMC, Barbosa REA, Bernhard TJA, Vasconcelos PRL 2006. Efeito do extrato de Passiflora edulis (maracujá) na cicatrização de bexiga em ratos: estudo morfológico. Acta Cir Bras 21: 3-8.

Hinneburg I, Neubert RHH 2005. Influence of extraction parameters on the phytochemical characteristics of extracts from buckwheat (Fagopyrum esculentum) Herb. J Agr Food Chem 53: 3-7.

Hui CW 2002. A review of modern sample preparation techniques for the extraction and analysis of medicinal plants. Anal Bioanal Chem 373: 23-30.

Huk-Kolega H, Skibska, B, Kleniewska P, Piechota A, Michalski Ł, Goraca A 2011. Role of lipoic acid in health and disease. Pol Merkur Lekarski 183: 183185.

IBGE 2008. Banco de Dados Agregados. Sistema IBGE de Recuperação Automática - SIDRA. http://www.ibge. gov.br, accessed in June 2009.

Linden R, Ortega GG, Petrovick PR, Bassani VR 2000. Response surface analysis applied to the preparations 
of tablets containing a high concentration of vegetable spray-dried extract. Drug Dev Ind Pharm 26: 441-446.

Liu FF, Ang CYW, Springer D 2000. Optimization of extraction conditions for active components in Hypericum perforatum: using response surface methodology. $J$ Agri Food Chem 48: 3364-3371.

Martinello T, Kaneko TM, Velasco MVR, Taqueda MES, Consiglieri VO 2006. Optimization of poorly compactable drug tablets using the mixture experimental design. Int $J$ Pharm 322: 87-95.

Montanher AB, Zucolotto SM, SchenkeL EP, Fröde TS 2007. Evidence of anti-inflammatory effects of Passiflora edulis in an inflammation model. J Ethnopharmacol 109: 281-288.

Müller V, Chávez JH, Reginatto FH, Zucolotto SM, Niero R, Navarro D, Yunes RA, Schenkel EP, Barardi CR, Zanetti CR, Simões CM 2007. Evaluation of antiviral activity of South American plant extracts against herpes simplex virus type 1 and rabies vírus. Phytother Res 21: 970-974.

Noriega P, Röpke CD, Camilo CM, Freitas PCD, Barros SBM 2005. Evaluation of extraction conditions of 4-nerolidylcatechol from Pothomorphe umbellata (L). Miq. using factorial design. Braz J Pharm Sci 41: 261269.

Noriega P, Röpke CD, Consiglieri VO, Taqueda ME, Tavares LC, Wasicky A, Bacchi EM, Barros SBM 2008. Optimization of Pothomorphe umbellata (L.) Miquel topical formulations using experimental design. Int $J$ Pharm 353: 149-159.

Noriega P, , Mafud DF, Strasser M, Kato ETM, Bacchi EM 2011. Passiflora alata Curtis: a Brazilian medicinal plant. Bol Latinoam Caribe Plant Med Aromat 10: 398-413.

Oga S, de Freitas PC, Gomes Da Silva AC, Hanada S 1984. Pharmacological trials of crude extract of Passiflora alata. Planta Med 50: 303-306.

Oliveira WP, Bott RF, Souza CRF 2006. Manufacture of standardized dried extracts from medicinal Brazilian plants. Dry Technol 24: 523-533.

Ong ES 2004. Extraction methods and chemical standardization of botanicals and herbal preparations. J Chromatogr 812: 23-33.

Ou B, Hampsch-Woodill M, Prior RL 2001. Development and validation of an improved oxygen radical absorbance capacity assay using fluorescein as the fluorescent probe. J Agric Food Chem 49: 4619-4626.

Peng B, Li R, Yan W 2009. Solubility of rutin in ethanol + water at (273.15 to 323.15) K. J Chem Eng Data 54: 13781381.

Petry RD, Reginatto F, de-Paris F, Gosmann G, Salgueiro JB, Quevedo J, Kapczinski F, Ortega GG, Schenkel EP 2001. Comparative pharmacological study of hydroethanol extracts of Passiflora alata and Passiflora edulis leaves. Phytother Res 15: 162-164.

Pharmacopeia dos Estados Unidos do Brasil 1926. São Paulo:
Companhia Editora Nacional.

Pozzi A 2007. Desenvolvimento de Métodos de Análise Espectrofotométrica de Flavonóides do "Maracujá" (Passiflora alata e Passiflora edulis). São Carlos, 86p. Dissertação de Mestrado, Programa de Pós-graduação em Química Analítica, Universidade de São Paulo.

Prior RL, Hoang H, Gu L, Wu X, Bacchiocca M, Howard L, Hampsch-Woodill M, Huang D, Ou B, Jacob R 2003. Assays for hydrophilic and lipophilic antioxidant capacity (oxygen radical absorbance capacity (ORACFL)) of plasma and other biological and food samples. J Agri. Food Chem 51: 3273-3279.

Reginatto FH, de-Paris F, Petry RD, Quevedo J, Ortega GG, Gosmann G, Schenkel EP 2006. Evaluation of anxiolytic activity of spray dried powders of two South Brazilian Passiflora species. Phytother Res 20: 348-351.

Ripa FA, Haque M, Nahar L, Islam MM 2009. Antibacterial, cytotoxic and antioxidant activity of Passiflora edulis Sims. Eur J Sci Res 31: 592-598.

Rudnicki M, Oliveira MR, Pereira TV, Reginatto FH, Dal-Pizzol F, Moreira JCF 2007a. Antioxidant and antiglycation properties of Passiflora alata and Passiflora edulis extracts. Food Chem 100: 719-724.

Rudnicki M, Silveira MM, Pereira TV, Oliveira MR, Reginatto FH, Dal-Pizzol F, Moreira JCF 2007. Protective effects of Passiflora alata extract pretreatment on carbon tetrachloride induced oxidative damage in rats. Food Chem Toxicol 45: 656-661.

Runha FP, Cordeiro DS, Pereira CAM, Vilegas J, Oliveira WP 2001. Production of dry extracts of medicinal Brazilian plants by spouted bed process: development of the process and evaluation of thermal degradation during the drying operation. Food Bioprod Process 79: 160168.

Silva IV, Ferreira MS, Warderley AG, Fernandes MJ, Soares LAL, De Souza LP 2009. Influence of extractive parameters on the preparation of a solution from Psidium guajava L. Lat Am J Pharm 28: 116-120.

Souza CRF, Bott RF, Oliveira WP 2007. Optimization of the extraction of flavonoids compounds from herbal material using experimental design and multi-response analysis. Lat Am J Pharm 26: 682-690.

Veras MCM, Pinto ACQ, Meneses JB 2000. Influência da época de produção e dos estádios de maturação nos maracujás doce e ácido nas condições de cerrado. Pesqui Agropecu Bras 35: 959-966.

Wang X, Kapoor V, Smythe GA 2003. Extraction and chromatography-mass spectrometric analysis of the active principles from selected chinese herbs and other medicinal plants. Am J Chin Med 31: 927-944.

Wasicky A 2007. Estudo farmacognóstico comparativo de Passiflora alata Curtis e Passiflora nitida Kunth (Passifloraceae). Avaliação das atividades antiúlcera e antioxidante dos seus extratos. São Paulo, 105 p. Dissertação de Mestrado, Programa de Pós-graduação 
em Fármaco e Medicamentos, Universidade de São Paulo.

Zi J, Peng B, Yan W 2007. Solubilities of rutin in eight solvents at $\mathrm{T}=283.15,298.15,3313.15,323.15$, and $33.15 \mathrm{~K}$. Fluid Phase Equilibr 261: 111-114.

\section{*Correspondence}

Elfriede M. Bacchi

Departamento de Farmácia, Faculdade de Ciências Farmacêuticas, Universidade de São Paulo

Av. Lineu Prestes 580, 05508-900 São Paulo-SP, Brazil elfriede@usp.br 